\title{
Contribution of moderate overall coal-bearing basin uplift to tight sand gas accumulation: case study of the Xujiahe Formation in the Sichuan Basin and the Upper Paleozoic in the Ordos Basin, China
}

\author{
Cong-Sheng Bian ${ }^{1} \cdot$ Wen-Zhi Zhao ${ }^{1} \cdot$ Hong-Jun Wang $^{1} \cdot$ Zhi-Yong Chen $^{1} \cdot$ \\ Ze-Cheng Wang ${ }^{1}$. Guang-Di Liu ${ }^{2}$ Chang-Yi Zhao ${ }^{1} \cdot$ Yun-Peng Wang ${ }^{3}$. \\ Zhao-Hui $\mathrm{Xu}^{1} \cdot$ Yong-Xin $\mathrm{Li}^{1} \cdot$ Lin Jiang ${ }^{1}$
}

Received: 7 May 2014/Published online: 22 April 2015

(C) The Author(s) 2015. This article is published with open access at Springerlink.com

\begin{abstract}
Tight sand gas is an important unconventional gas resource occurring widely in different petroleum basins. In coal-bearing formations of the Upper Triassic in the Sichuan Basin and the Carboniferous and Permian in the Ordos Basin, coal measure strata and tight sandstone constitute widely distributed source-reservoir assemblages and form the basic conditions for the formation of large tight sand gas fields. Similar to most tight gas basins in North America, the Sichuan, and Ordos Basins, all experienced overall moderate uplift and denudation in MesoCenozoic after earlier deep burial. Coal seam adsorption principles and actual coal sample simulation experiment results show that in the course of strata uplift, pressure drops and desorption occurs in coal measure strata, resulting in the discharge of substantial free gas. This accounts for $28 \%-42 \%$ of total gas expulsion from source rocks. At the same time, the free gases formerly stored in the pores of coal measure source rocks were also discharged at a large scale due to volumetric expansion resulting from strata uplift and pressure drop. Based on experimental data, the gas totally discharged in the uplift period of Upper Paleozoic in the Ordos Basin, and Upper Triassic Xujiahe Formation in the Sichuan Basin is calculated as (3-6) $\times 10^{8} \mathrm{~m}^{3} / \mathrm{km}^{2}$. Geological evidence for gas
\end{abstract}

Cong-Sheng Bian

bcs_1981@petrochina.com.cn

1 Research Institute of Petroleum Exploration \& Development, CNPC, Beijing 100083, China

2 College of Geosciences, China University of Petroleum, Beijing 102249, China

3 Guangzhou Institute of Geochemistry, Chinese Academy of Sciences, Guangzhou 510640, Guangdong, China

Edited by Jie Hao accumulation in the uplift period is found in the gas reservoir analysis of the above two basins. Firstly, natural gas discharged in the uplift period has a lighter carbon isotope ratio and lower maturity than that formed in the burial period, belonging to that generated at the early stage of source rock maturity, and is absorbed and stored in coal measure strata. Secondly, physical simulation experiment results at high-temperature and high-salinity inclusions, and almost actual geologic conditions confirm that substantial gas charging and accumulation occurred in the uplift period of the coal measure strata of the two basins. Diffusive flow is the main mode for gas accumulation in the uplift period, which probably reached $56 \times 10^{12} \mathrm{~m}^{3}$ in the uplift period of the Xujiahe Formation of the Sichuan Basin, compensating for the diffusive loss of gas in the gas reservoirs, and has an important contribution to the formation of large gas fields. The above insight has promoted the gas resource extent and potential of the coal measure tight sand uplift area; therefore, we need to reassess the areas formerly believed unfavorable where the uplift scale is large, so as to get better resource potential and exploration prospects.

Keywords Sichuan Basin · Ordos Basin · Tight sand gas · Stratigraphic uplift · Coal measure · Hydrocarbon accumulation mechanism $\cdot$ Diffusion

\section{Introduction}

Tight sand gas resources are widely distributed in the world (Masters 1979; Law 2002; Holditch 2006). Statistics show that tight sand gas has been discovered or predicted in 70 basins in North America, Europe, and the Asian-Pacific region, with a resource extent of about $210 \times 10^{12} \mathrm{~m}^{3}$, 
showing huge potential in exploration and development (British Petroleum Company 2012). The United States has the highest annual gas yield from tight sandstone at present in the world, reaching $1.75 \times 10^{8} \mathrm{~m}^{3}$ in 2010 , about $29 \%$ of total gas production of the country (British Petroleum Company 2012). In China, the Zhongba tight gas field was discovered in the western Sichuan Basin in 1971. With the progress in exploration technologies in recent years, new discoveries are continually being made. Two major tight gas provinces in the Sichuan and Ordos Basins and five breakthrough areas in the Kuche deep zone of the Tarim Basin have been found so far (Fig. 1), with technically recoverable gas resources of $8-11 \mathrm{TCM}$, and annual tight gas yield more than 25.6 BCM in 2011 (Li et al. 2012; Zou et al. 2012). Unconventional gas (i.e., tight gas and shale gas) is increasingly becoming one of the dominant resources in the global natural gas industry, and more efforts are being put into tight gas exploration in many countries (Kuuskraa and Bank 2003; Smith et al. 2009; Zeng 2010; Dai et al. 2012; He et al. 2013).

Statistics show that tight gas resources worldwide mostly originate from coal measure source rocks (Dai et al. 2012), e.g., the Piceance Basin (Johnson and Rice 1990;
Zhang et al. 2008) and the San Juan Basin (Ayers 2002) in the United States, the Ordos and Sichuan Basins in China. As well, in the formation and development history of these petroleum basins, the strata were usually deposited and buried, followed by uplifting at a later stage. The study by Tissot and Welte (1984) shows that natural gas generated in gas source rocks due to high temperature in the process of burial was either discharged, migrated, and accumulated in the reservoirs to form gas pools or was retained in the gas source rocks to form shale gas and coalbed methane. There are limited publications at home and abroad regarding natural gas migration and accumulation under uplift tectonic settings (Tian et al. 2007). It is usually believed that strata denudation and faulting are likely to occur in the course of uplifting, resulting in damage to gas reservoirs and dissipation of the gas (Hao et al. 1995; Zhang et al. 1999). Based on studies of tight sand gas accumulation in coal-bearing strata in recent years, we have found that tight gas from coal measure strata not only can form gas reservoirs in the course of deposition and burial, but also can accumulate in the moderate uplift process if the regional seal has not been destroyed (Bian et al. 2009; Zhao et al. 2010). This paper mainly takes gas

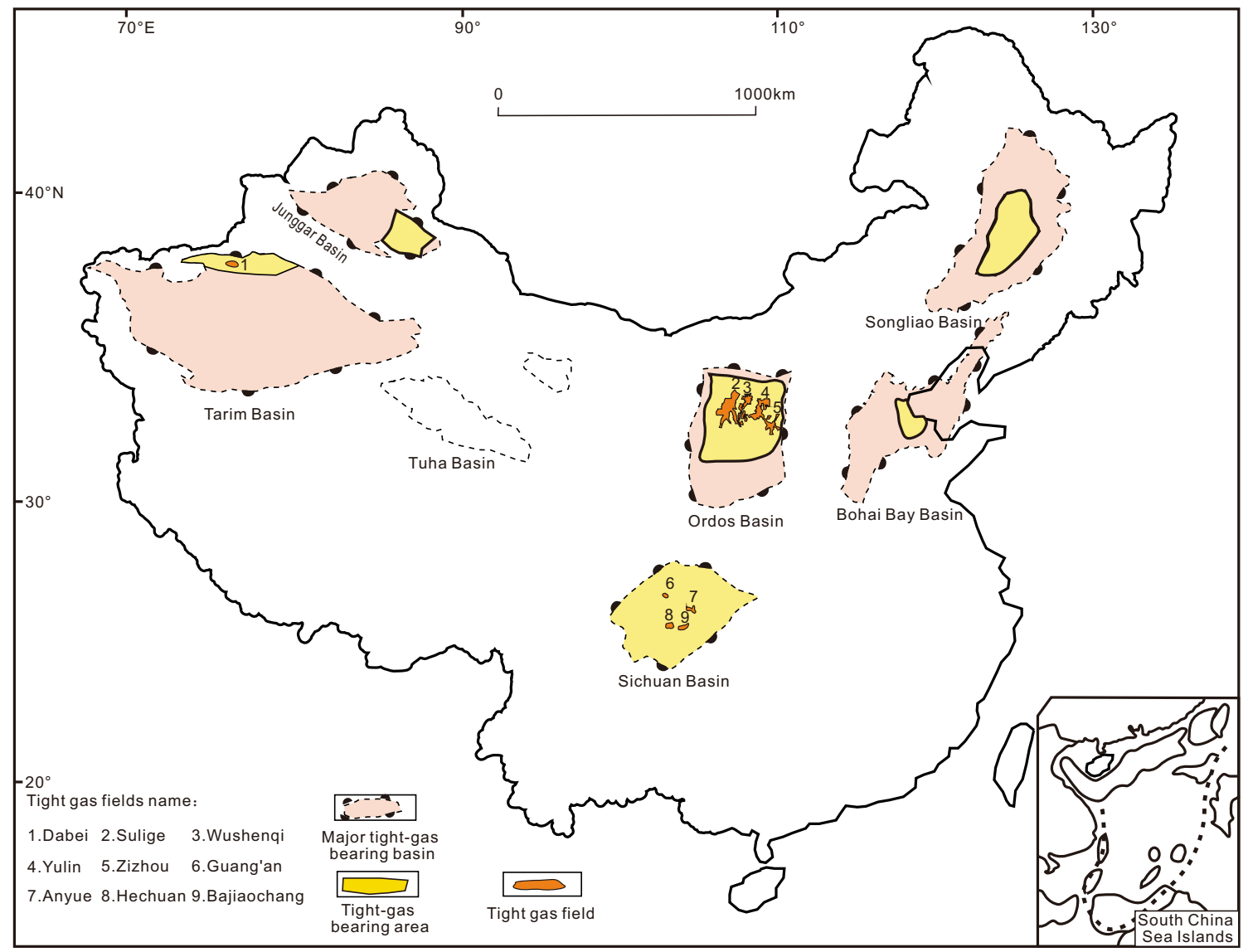

Fig. 1 Major tight sand gas basins in China 
fields of the Upper Triassic Xujiahe Formation in the Sichuan Basin and the Upper Paleozoic in the Ordos Basin as examples to discuss this geological process.

\section{Geological setting}

Several large gas fields with reserves more than 100 BCM have been successively discovered in the Upper Paleozoic Permo-Carboniferous in the Ordos Basin and the Upper Triassic Xujiahe Formation in the central Sichuan Basin (Dai et al. 2012; Zhao et al. 2013) in recent years. By the end of 2011, large gas fields like Sulige, Wushenqi, and Yulin had been discovered in Upper Paleozoic of the Ordos Basin, with proved gas reserves (including basically proved reserves) approaching $3.0 \times 10^{12} \mathrm{~m}^{3}$ and gas-bearing area about $2.0 \times 10^{4} \mathrm{~km}^{2}$. Large gas fields like Guang'an, Hechuan, and Anyue had been discovered in the Upper Triassic Xujiahe Formation of the Sichuan Basin, with proved gas reserves approaching $6000 \times 10^{8} \mathrm{~m}^{3}$ and gasbearing area of more than $3000 \mathrm{~km}^{2}$. Tight sand gas resources of the two basins account for more than two-thirds of the present total tight gas resources in China (Dai et al. 2012).

A set of continental clastic coal-bearing formations covering the whole basin is developed in the Upper Paleozoic of the Ordos Basin and the Xujiahe Formation of the Sichuan Basin, respectively, and the source rocks mainly consist of coal seams and coaly mudstone with high gas generation potential. The Upper Paleozoic source rocks of the Ordos Basin are distributed in the Carboniferous Taiyuan Formation and Permian Shanxi Formation (Zhang et al. 2009b), with coal seam thicknesses of 10-25 m on average, $40 \mathrm{~m}$ locally, almost covering the whole basin stably. Coal measure mudstones have thicknesses of 60-130 m, almost the same distribution as the coal seams, and are usually $200-\mathrm{m}$ thick in the west. The Upper Triassic Xujiahe Formation source rocks of the Sichuan Basin are distributed in the Xu1, Xu3, and Xu5 Members, with coal seam thicknesses of 5-15 $\mathrm{m}$ on average, distributed stably horizontally. Coal measure mudstones have thicknesses of 100-800 m, thinning out from the western to the central Sichuan Basin, basically covering the whole basin (Zhao et al. 2011). Thermal evolution history shows that substantial gas generation and expulsion occurred in the source rocks of the two basins in the geological history. The thermal evolution of source rocks has been at highly mature and overmature stages up to now, with cumulative gas generating strength of $(20-40) \times 10^{8} \mathrm{~m}^{3} / \mathrm{km}^{2}$ and $(40-100) \times 10^{8} \mathrm{~m}^{3} / \mathrm{km}^{2}$, respectively. This can provide abundant gas sources for large-scale gas accumulation in the tight sand reservoirs of the two large gas provinces. Their reservoirs are the Permian Shanxi and Shihezi
Formations and the Upper Triassic Xu2, Xu4, and Xu6 Member tight sands, respectively (Zhang et al. 2009a), with porosities of $4 \%-10 \%$, permeabilities of $0.01-1 \mathrm{mD}$ and thicknesses of hundreds to a thousand meters. They closely and widely contact the source rocks, comprising a very favorable source-reservoir assemblage horizontally, which has laid the foundation for widespread gas accumulation in the reservoirs and then the discovery of large scale reserves (Figs. 2, 3).

Stratigraphic burial history shows that the tight sand gas zones in both the Ordos Basin and the Sichuan Basin all experienced deep burial before the Late Cretaceous (Zhao et al. 2005, 2010), with maximum burial depths up to 3500-4000 m and 4500-6000 m, respectively. From the Late Cretaceous to this day, overall tectonic uplift and strata denudation occurred in these two basins, and the hydrocarbon generation of the source rocks stopped. The denuded thickness is $800-1500$ and $1500-2500 \mathrm{~m}$, respectively, and the buried depth of tight gas zones of these two basins is $1800-4000 \mathrm{~m}$ at present. Fortunately, uplift and denudation have not resulted in the damage to the regional seal.

\section{Theoretical model and experiment}

Substantial gas infusion is a prerequisite for gas accumulation in the uplift period of tight sand formation. Coal petrography (Wang et al. 1995; Zhang et al. 2000) showed that microfractures and cleats are well developed in coals, especially in high-rank coals. Substantial free gas was stored in pores and microfractures at the time of substantial gas generating from coal seams in the burial period. This expanded volumetrically due to the pressure drop in the uplift period, and thus together with the desorbed and liberated coal seam gas, became the important gas source for gas accumulation in the uplift period (Cui et al. 2005; Zhao et al. 2010). Starting from the discussion of a theoretical model of coal seam adsorption-desorption, by means of thermal simulation and gas accumulation simulation experiments of actual coal samples, the geological process of gas accumulation in the uplift period of coal measure strata is demonstrated.

\subsection{Theory of adsorption of gas in coal seams and the experimental model}

Adsorption refers to the attachment of atoms or molecules of one substance on the surface of another substance (Busch et al. 2003; Bae and Bhatia 2006). The adsorption behavior of coal was observed in coal mining in the middle of the last century. After having successfully produced coalbed methane, the United States made an in-depth study 

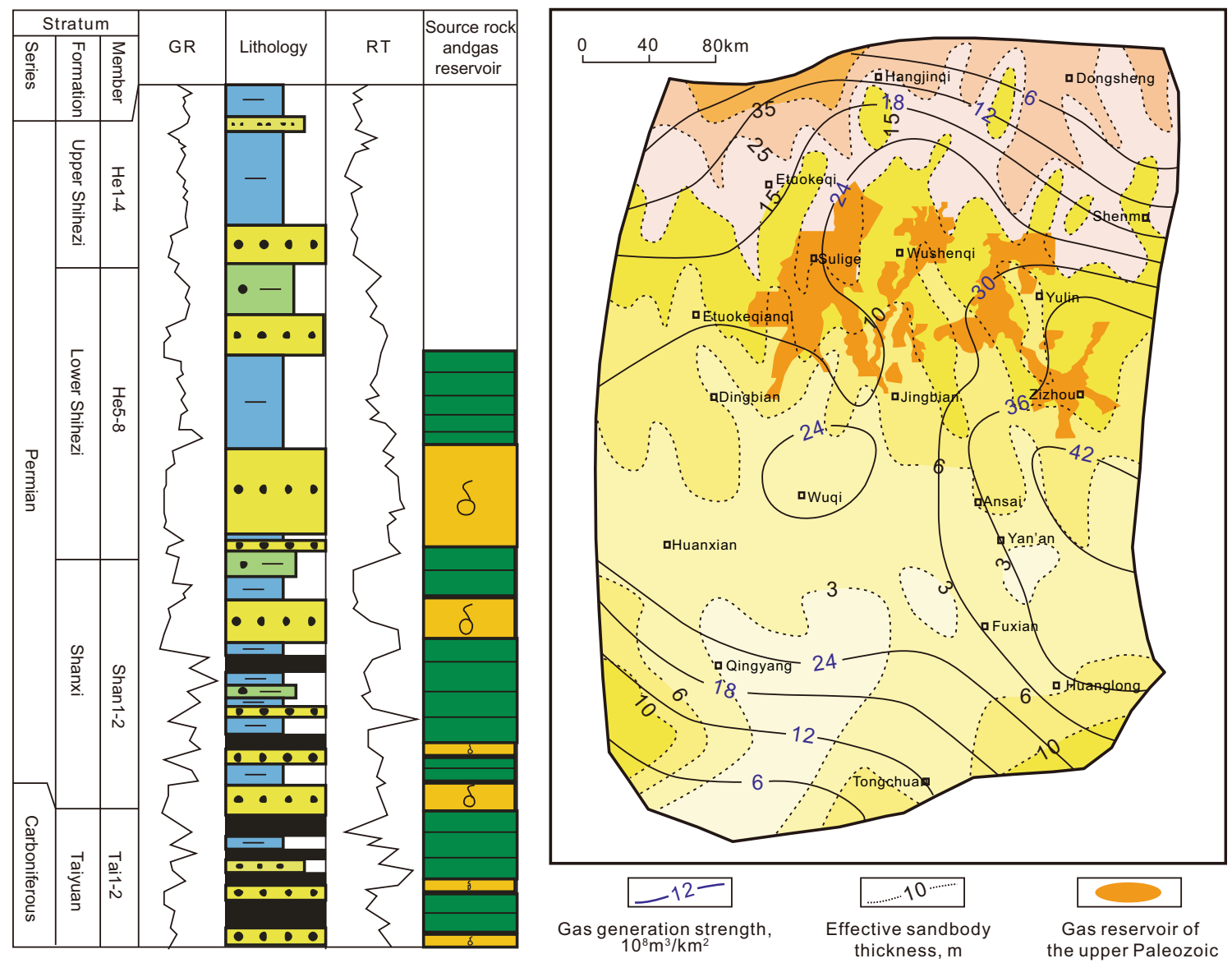

Fig. 2 Composite Upper Paleozoic stratigraphic section and coalbeds and He8 reservoirs, Ordos Basin
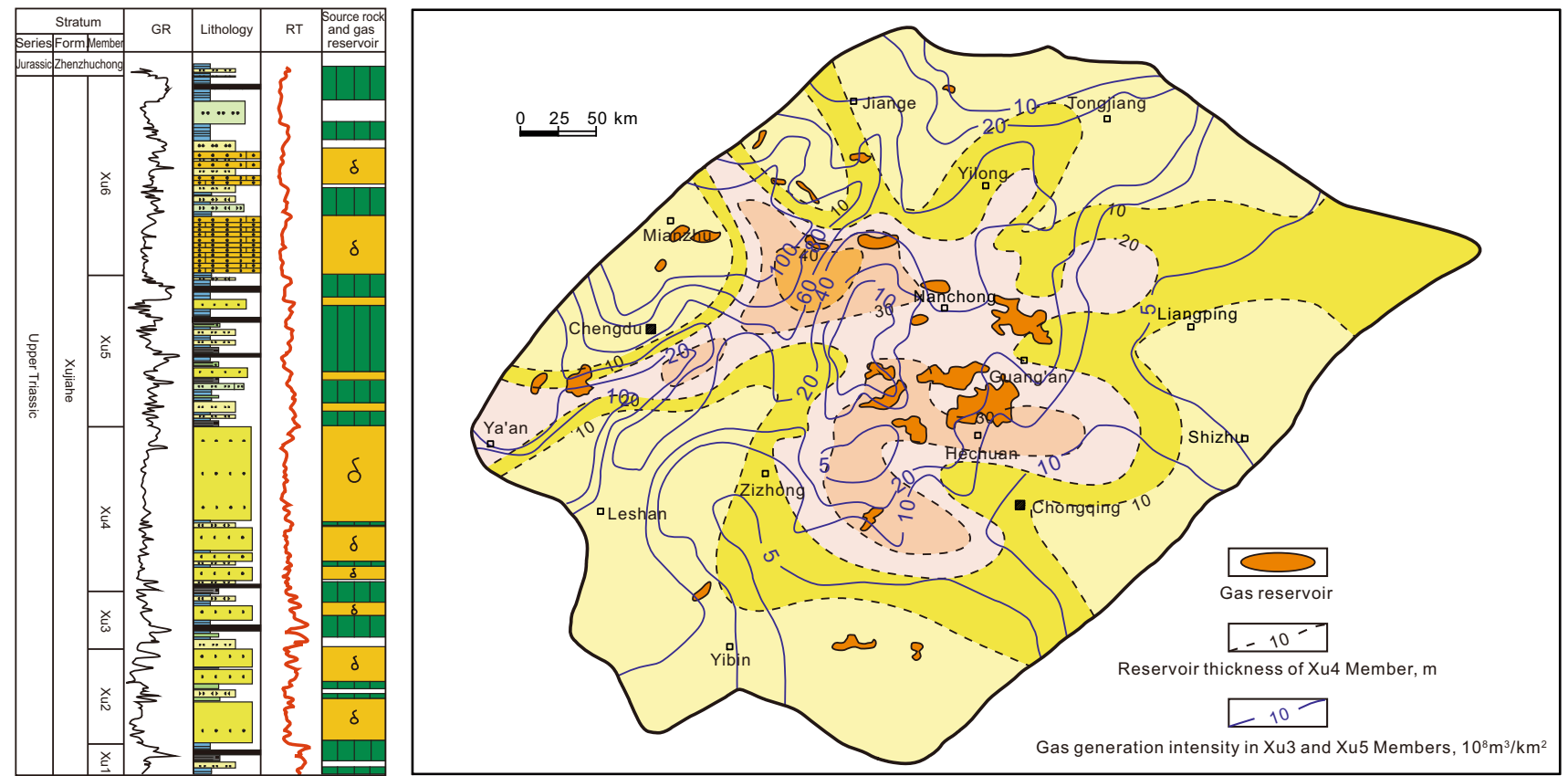

Fig. 3 Xujiahe stratigraphic section showing gas source rocks and reservoirs, Sichuan Basin 
on the adsorptive action of coal seams (Radovic et al. 1997; Clarkson and Bustin 1999). Coal is universely believed at present to be a porous medium with a big surface area. The adsorption of gas by coal is a physical adsorption process; the adsorption energy (heat) is small, the adsorption rate is fast, and the adsorption and desorption procedure is reversible (Radovic et al. 1997; Clarkson and Bustin 1999). Therefore, the adsorptive force of coal to gas molecules is intermolecular force, i.e., there are both adsorption equilibrium and adsorption heat (energy). Previous studies (Mavor et al. 1990; Mukhopadhyay and Macdonald 1997; Crosdale et al. 1998) show that the adsorption by coal seams is affected by many factors like coal composition, temperature and pressure, gas properties, and coal rank. Under geological conditions, with the variation of buried depth of coal seams, the impact of temperature and pressure on it is maximum. Experimental results show that pressure is proportional to adsorptive capacity, whereas the influence of temperature is the reverse (Zhao et al. 2001).

Many researchers (Anderson et al. 1966; Ruppel et al. 1974; Yang and Saunders 1985) have conducted many theoretical and experimental studies on the adsorptive action of coal seams and established many theoretical models and mathematical expressions related to adsorptive capacity. These include the monomolecular layer adsorption model and Langmuir's equation, multimolecular layer adsorption model and BET's equation, Freundlieh's equation, Polomyi's adsorption potential theory, micropore filling theory, and Dubinin-Astak-hov's equation (Sang et al. 2005; Su et al. 2008). However, it is difficult to accurately describe the adsorptive properties of coal using a certain isothermal adsorption line or theoretical model due to the presence of micropores in coal. It is generally believed that gas is adsorbed on the surface of coal in a monomolecular state under geological conditions; therefore, a monomolecular layer adsorption model and Langmuir's equation are widely used to describe the adsorptive features of coal and have become a classical theory maturely used in the development of coalbed methane for the moment. The model is described as follows:

$V=\frac{V_{\mathrm{L}} \times P}{P_{\mathrm{L}}+P}$

where $V$ represents the adsorptive capacity of coal, $V_{\mathrm{L}}$ is the Langmuir volume, $P_{\mathrm{L}}$ is Langmuir pressure, and $P$ is pressure.

With increasing research, it is found that under subsurface high temperature and pressure conditions (pressure $>15 \mathrm{MPa}$, temperature $>80{ }^{\circ} \mathrm{C}$ ) (Gregory and Karen 1986; Mavor et al. 1990), multimolecular layer adsorption of gas occurs in coal seams. As well, methane becomes a supercritical gas under high pressure, and its density increases significantly, resulting in a change of adsorptive capacity. This results in the phenomenon that the adsorptive capacity measured experimentally represents the maximum value and then declines, i.e., there is a large difference between the measured apparent adsorption capacity and the absolute adsorptive capacity. To help solve this problem, some correction models for calculating the adsorptive capacity are introduced (Haydel and Kobayashi 1967; Murata et al. 2001), and a relatively common method is as follows:

$N_{\text {ab }}=N_{\text {ap }}\left(1-\rho_{\text {free }} / \rho_{\text {ad }}\right)$

where $N_{\text {ab }}$ represents absolute adsorptive capacity, $N_{\text {ap }}$ is excessive adsorptive capacity or apparent adsorptive capacity, $\rho_{\text {free }}$ is free gas density under equilibrium conditions, and $\rho_{\text {ad }}$ is the adsorbed gas density.

Because of equipment limitations, most coal adsorption experiments are conducted at temperatures less than $40{ }^{\circ} \mathrm{C}$ and pressures less than $15 \mathrm{MPa}$, and the relation between pressure and adsorptive capacity is basically measured at one temperature. There are few experimental studies with both temperature and pressure varying. Cui et al. (2005) derive a characteristic curve for coal-adsorbed methane based on adsorption potential theory and adsorption experiments under high temperature and high pressure and believe that this characteristic curve has uniqueness, i.e., there is only a unique peak value in adsorptive capacity, based on which a new adsorption model of coal is derived and can be used to estimate the adsorptive capacity at different temperature-pressure conditions.

$\ln V=A T[2.7 \ln T-\ln P-12.6603]+B$

where $A$ and $B$ stand for adsorption constant and can be obtained from experimental adsorptive data of coal at a given temperature. The above equation can be used to calculate the adsorptive capacity of coal at any temperature and pressure.

\subsection{Simulation experiment of hydrocarbon expulsion due to coal seam uplift and pressure drop}

For the sake of understanding gas desorption due to temperature and pressure drop under approximately real geological conditions, a specially designed autoclave was used to simulate the gas discharge process of coal seams at the time of dropping of temperature and pressure. Two and five sets of samples were selected from the Upper Triassic Xujiahe Formation of the Sichuan Basin and the Upper Paleozoic of the Ordos Basin, repectively, to conduct the experiments. The deep burial and gas generation process of coal seams was simulated by external heating and pressurizing; when gas generation and expulsion reached equilibrium in the autoclave, the temperature and pressure were reduced, and the gas discharge from coal was observed. The experimental results are listed in Table 1 and 
Table 1 Gas expulsion of coals under different temperature and pressure conditions

\begin{tabular}{|c|c|c|c|c|c|c|c|}
\hline Coal sample & Process & $\begin{array}{l}\text { Temperature, } \\
{ }^{\circ} \mathrm{C}\end{array}$ & $\begin{array}{l}\text { Pressure, } \\
\mathrm{MPa}\end{array}$ & $\begin{array}{l}\text { Gas } \\
\text { generation } \\
\text { and expulsion, } \\
\mathrm{mL}\end{array}$ & $\begin{array}{l}\text { Total gas } \\
\text { generation } \\
\text { and expulsion } \\
\text { rate, } \mathrm{mL} / \mathrm{g}\end{array}$ & $\begin{array}{l}\text { Staged gas } \\
\text { generation } \\
\text { and expulsion } \\
\text { rate, } \mathrm{mL} / \mathrm{g}\end{array}$ & $\begin{array}{l}\text { Staged } \\
\text { gas generation } \\
\text { and expulsion } \\
\text { ratio, \% }\end{array}$ \\
\hline \multirow[t]{2}{*}{ Xu3 member } & Heating and pressurizing & 420 & 105 & 75 & \multirow[t]{2}{*}{48.8} & 32.7 & 67 \\
\hline & Cooling and depressurizing & 320 & 50 & 37 & & 16.1 & 33 \\
\hline \multirow[t]{2}{*}{ Xu6 member } & Heating and pressurizing & 420 & 105 & 575 & \multirow[t]{2}{*}{40} & 28.8 & 72 \\
\hline & Cooling and depressurizing & 320 & 50 & 225 & & 11.3 & 28 \\
\hline \multirow[t]{2}{*}{ Liaohe lignite } & Heating and pressurizing & 450 & 104 & 475 & \multirow[t]{2}{*}{19.4} & 11.9 & 61.3 \\
\hline & Cooling and depressurizing & 350 & 60 & 300 & & 7.5 & 38.7 \\
\hline \multirow[t]{2}{*}{ Xianfeng lignite } & Heating and pressurizing & 450 & 6 & 850 & \multirow[t]{2}{*}{73.3} & 42.5 & 58 \\
\hline & Cooling and depressurizing & 350 & 2 & 615 & & 30.8 & 42 \\
\hline \multirow[t]{2}{*}{ Xianfeng lignite } & Heating and pressurizing & 450 & 8.2 & 950 & \multirow[t]{2}{*}{79.5} & 47.5 & 59.7 \\
\hline & Cooling and depressurizing & 350 & 4 & 640 & & 32.0 & 40.3 \\
\hline \multirow[t]{2}{*}{ Taiyuan Formation } & Heating and pressurizing & 450 & 4.1 & 826 & \multirow[t]{2}{*}{60.8} & 41.3 & 67.9 \\
\hline & Cooling and depressurizing & 350 & 2.4 & 390 & & 19.5 & 32.1 \\
\hline \multirow[t]{2}{*}{ Shanxi Formation } & Heating and pressurizing & 450 & 4.4 & 975 & \multirow[t]{2}{*}{70.3} & 48.8 & 69.4 \\
\hline & Cooling and depressurizing & 350 & 1 & 430 & & 21.5 & 30.6 \\
\hline
\end{tabular}

show that when the temperature and pressure of coals taken from the Xujiahe Formation are reduced from $420{ }^{\circ} \mathrm{C}$ and $105 \mathrm{MPa}$ to $320{ }^{\circ} \mathrm{C}$ and $50 \mathrm{MPa}$, respectively (corresponding to uplifting of formation from 4000 to $2000 \mathrm{~m}$ ), the desorbed and discharged gas is $11-16 \mathrm{~mL} / \mathrm{g}$, accounting for $28 \%-33 \%$ of total gas expulsion of coals. When the temperature and pressure of coals from the Upper Paleozoic of the Ordos Basin are reduced from $450{ }^{\circ} \mathrm{C}$ and 104-4 MPa to $350{ }^{\circ} \mathrm{C}$ and $60-1 \mathrm{MPa}$, respectively (corresponding to uplifting the formation from $4000-6000 \mathrm{~m}$ to less than $3000 \mathrm{~m}$ ), the desorbed and discharged gas is $7.5-32 \mathrm{~mL} / \mathrm{g}$, accounting for $31 \%-42 \%$ of total gas expulsion, showing that quite a lot of gas is desorbed and discharged during the temperature and pressure decline process of coal seams in the uplift period.

\subsection{Physical simulation of gas accumulation}

Physical simulation is an important method to study and reproduce geological processes (Zeng and Jin 2002; Zhao et al. 2006). To better study the gas accumulation process of coal measure tight sand formations in the uplift period, an experiment was conducted to simulate gas migration and accumulation under strata uplift and pressure drop settings. To prove the existence of gas desorption and expulsion from coal measure formations in its uplift and pressure drop, a physical simulation experiment model was designed based on the configuration relation of source rocks and reservoirs of the Upper Triassic Xujiahe Formation in the Sichuan Basin. Coal samples were crushed to 150-200 mesh, sandstone was replaced by glass beads, and natural gas in the formation was approximated by pure methane. A 3D high-temperature and high-pressure physical simulation device independently designed by RIPED was used for experiment.

In the experiment (Table 2), the model was evacuated, then water was injected, and overburden pressure was applied to simulate the water discharge process of formations due to burial and compaction. When the overburden pressure was increased to $7 \mathrm{MPa}$, the fluid pressure reached 1.63 $\mathrm{MPa}$ at $60{ }^{\circ} \mathrm{C}$, and the formation was saturated with water and was in a near-equilibrium state. Then, methane was injected into the bottom of the model to simulate the gas generation process. In the course of gas injection, water was continually discharged from the outlet. When the experiment had been conducted for about $20 \mathrm{~h}$, gas started to appear at the outlet, showing that after the gas source rock had been saturated with adsorbed gas, free gas started to migrate. When the gas flowing out of the outlet reached $10 \mathrm{~mL} / \mathrm{min}$ and the water yield decreased significantly, we stopped the gas injection. This simulates the uplift and pressure drop process, and the gas desorption and gas expulsion processes were observed. To better replicate the subsurface environment, we stopped any operation for $24 \mathrm{~h}$ after having ceased gas injection, to ensure the equilibration of gas filling and adsorption. This simulates the cessation of gas generation after the source rock reached its maximum buried depth. Subsequently, the overburden pressure, fluid pressure, and temperature of the model were reduced, and at 175-182 $\mathrm{h}$ later, gas flowed out of the outlet in an episodic type. This process corresponds to that after the formation had changed from burial to uplift and 
Table 2 Experiment process and phenomena

\begin{tabular}{|c|c|c|c|}
\hline Step & Process and phenomena & Step & Process and phenomena \\
\hline 1 & Installed model under dry and water free conditions & 7 & Increased injection pressure, gas started to appear at outlet \\
\hline 2 & Evacuated for $12 \mathrm{~h}$ & 8 & $\begin{array}{l}\text { When the outflow rate of methane reached } 10 \mathrm{~mL} / \mathrm{min} \text {, the injection } \\
\text { pressure was } 2 \mathrm{MPa} \text {, closed the gas inlet }\end{array}$ \\
\hline 3 & $\begin{array}{l}\text { Slowly injected water into model from the bottom until } \\
\text { the internal pressure is at } 1 \mathrm{MPa} \text { uniformly }\end{array}$ & 9 & $\begin{array}{l}\text { The gas outflow rate gradually decreased below } 0.1 \mathrm{~mL} / \mathrm{min} \text {, and the } \\
\text { fluid pressure decreased gradually too }\end{array}$ \\
\hline 4 & $\begin{array}{l}\text { Allowed fluid pressure to be } 1.63 \mathrm{MPa} \text {, increased } \\
\text { overburden pressure to } 7 \mathrm{MPa} \text {, and heated the model to } \\
60{ }^{\circ} \mathrm{C}\end{array}$ & 10 & When no further gas flowed out of the outlet, stood still for $24 \mathrm{~h}$ \\
\hline 5 & $\begin{array}{l}\text { Injected methane at pressure more than } 1.63 \mathrm{MPa} \text {, water } \\
\text { flow rate at outlet increased gradually }\end{array}$ & 11 & $\begin{array}{l}\text { Gradually reduced the overburden pressure to } 2 \mathrm{MPa} \text {, the fluid pressure } \\
\text { did not change; reduced temperature to } 30^{\circ} \mathrm{C} \text {, recorded the gas flow } \\
\text { rate at outlet }\end{array}$ \\
\hline 6 & $\begin{array}{l}\text { Water flow rate decreased gradually after having been } \\
\text { increased to } 40 \mathrm{~mL} / \mathrm{h}\end{array}$ & 12 & $\begin{array}{l}\text { Gradually reduced the fluid pressure of model to } 1.63 \mathrm{MPa} \text {, the } \\
\text { overburden pressure and temperature did not change, recorded the gas } \\
\text { flow rate at outlet }\end{array}$ \\
\hline
\end{tabular}

(a)
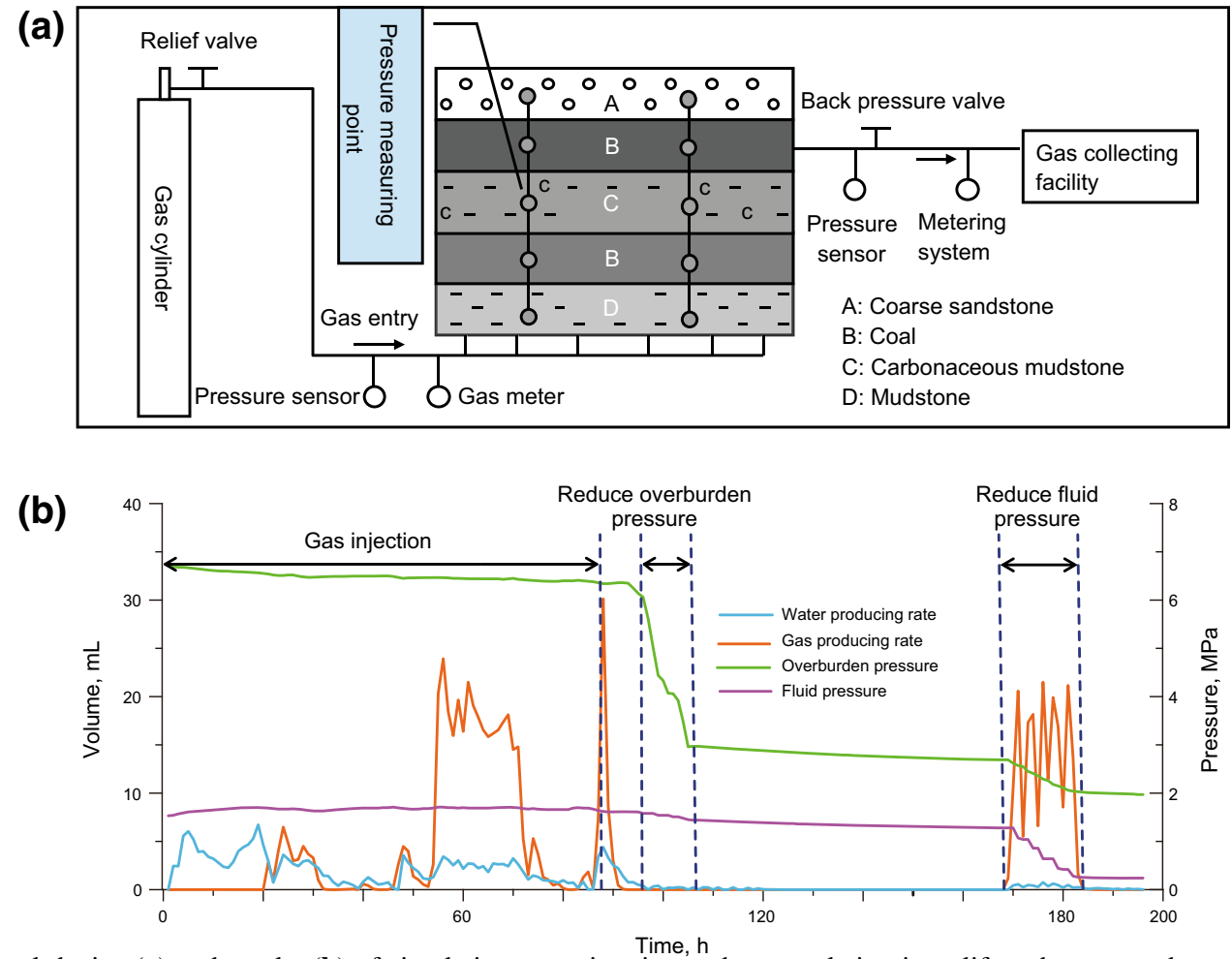

Fig. 4 Experimental device (a) and results (b) of simulating gas migration and accumulation in uplift and pressure drop environment

denudation when the temperature and pressure of the formation fluid had dropped. Desorption occurred in the coal measure formation, gas was liberated, and substantial gas migrated (Fig. 4a, b).

\section{Experimental results and analysis}

The above experiment shows that under uplift settings, although the gas generation process of gas source rocks had stopped, the substantial gas adsorbed on the particle surfaces inside the source rocks and free in the pores and highly compressed in deep strata suffered from desorption and bulk expansion due to pressure drop in the course of uplift. This generated power to force the gas to escape outward from the source rocks, and the gas can still largely migrate and accumulate. The existence of this process can enlarge the gas exploration realm to the "poor" gas accumulation area, i.e., gas reservoirs can still be found in the uplift area where gas reservoirs were formerly not believed to develop.

The gas discharged from different thickness coal seams in the two basins due to temperature and pressure drop in the course of moderate uplift at late stage can be 


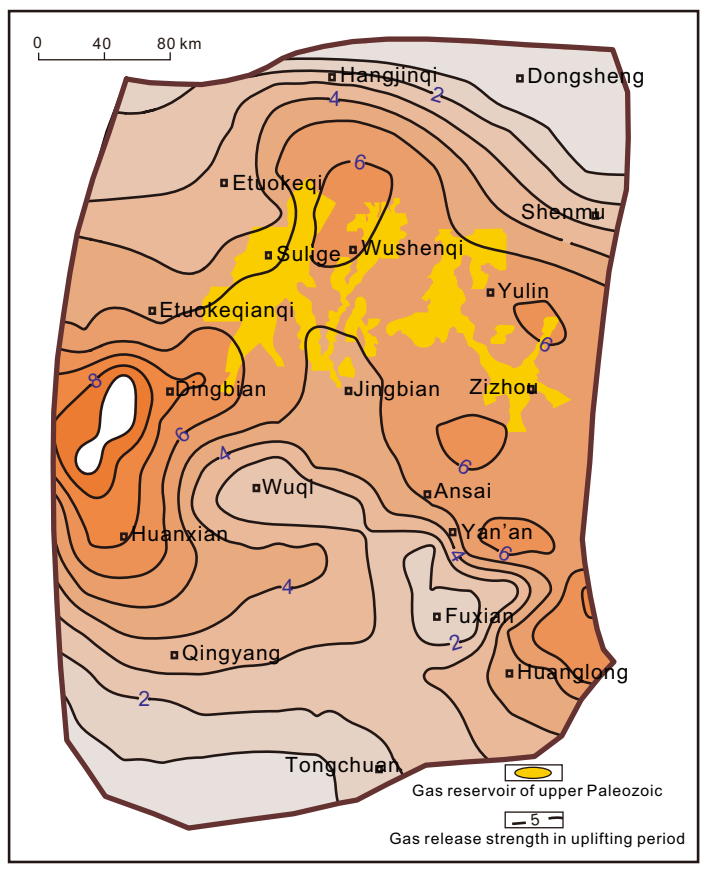

Fig. 5 Gas release strength in the uplift period of the Upper Paleozoic, Ordos Basin (unit: $\times 10^{8} \mathrm{~m}^{3} / \mathrm{km}^{2}$ )

quantitatively estimated based on the simulation experiment results (Table 1) and the coal seam adsorptiondesorption equations (Eqs. 2, 3). The strength of desorption and discharge of gas from coal seams in the uplift period is obtained based on calculation and statistics of data obtained from about 300 wells in the two basins, as shown in Figs. 5 and 6. Observed from these two figures, the gas expulsion area formed by pressure drop and desorption of coal seams of both the Ordos Basin and the Sichuan Basin in the uplift period can reach $(15-18) \times 10^{4} \mathrm{~km}^{2}$. The gas expulsion strength is basically $(2-8) \times 10^{8} \mathrm{~m}^{3} / \mathrm{km}^{2}$, and the high value areas have corresponded well to the discovered gas fields, showing that the uplift period has provided important gas supply for large-scale gas accumulation in the two large gas provinces.

\section{Geological evidence}

\subsection{Fluid inclusions}

Fluid inclusions provide important means to study the gas accumulation process (Wang and Tian 2000; Rossi et al. 2002; Lu 2005). The study of inclusions from the Xujiahe Formation reservoir in the central Sichuan Basin (Fig. 7; Table 3) showed that two stages of hydrocarbon inclusions can be clearly identified based on their occurrence and fluorescent display characteristics. The first stage of hydrocarbon inclusions was developed in the early stage of quartz overgrowth, mainly occurring at the inner side of quartz overgrowth or along micro-fracture planes in the early diagenesis of quartz grains, orange-red or light brownish yellow in fluorescent light (upper part of Fig. 7),

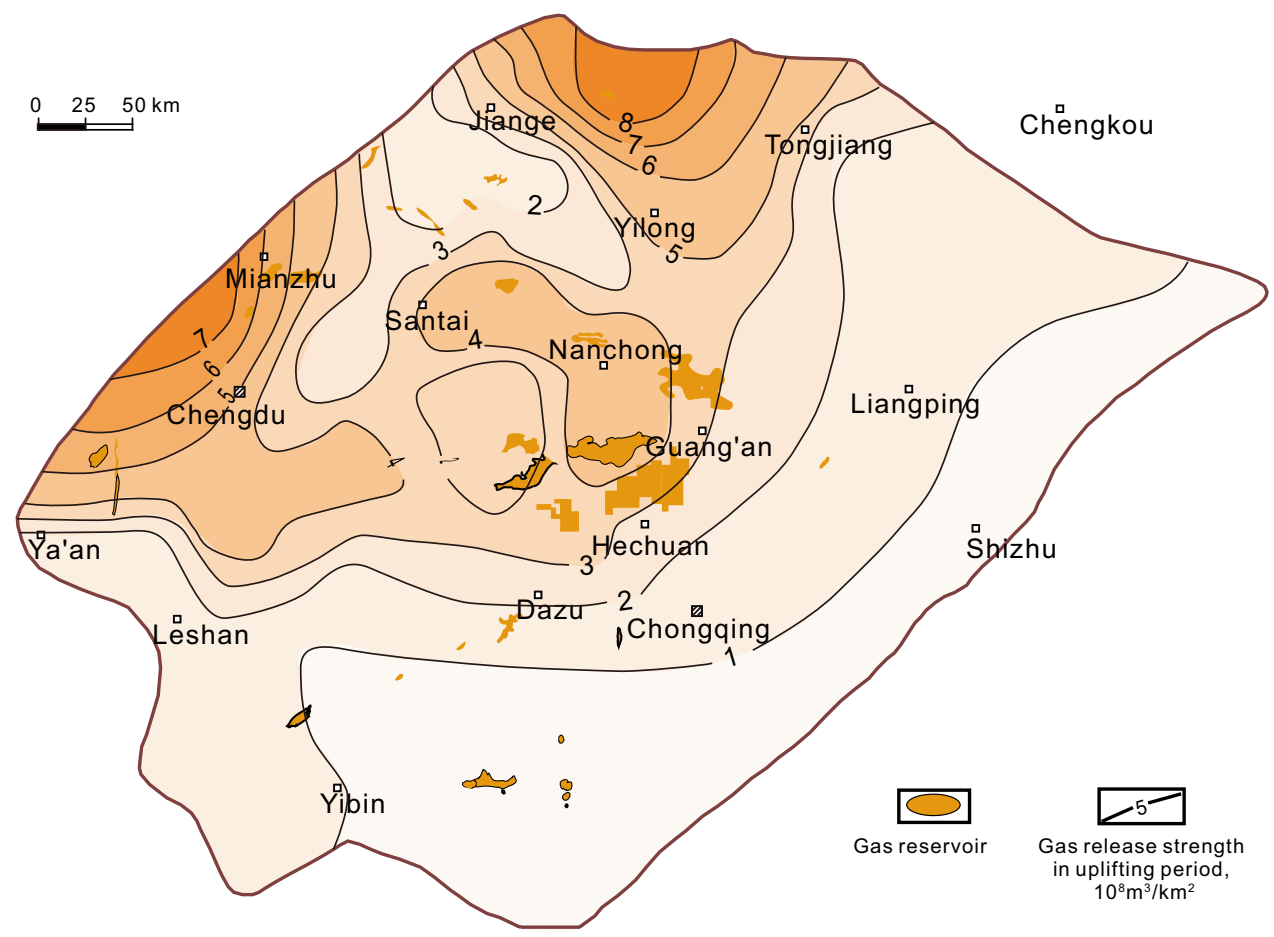

Fig. 6 Gas release strength in the uplift period of the Xujiahe coal measures and carbonaceous mudstones 

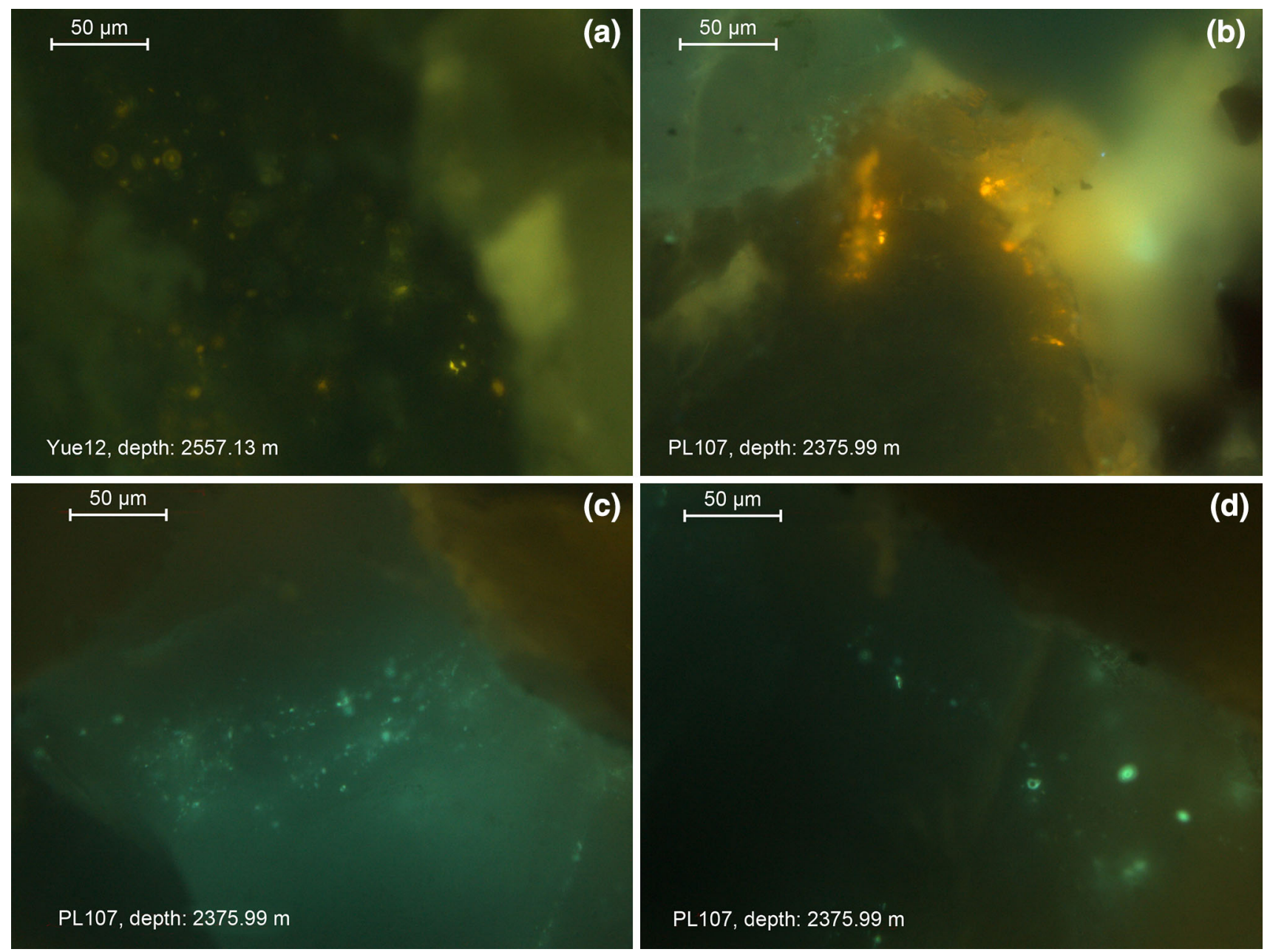

Fig. 7 Occurrence \& fluorescent light features for fluid inclusions in Xu 2 Formation, Penglai area, Central Sichuan Basin. a/b-fluid inclusions in the inner side of quartz overgrowth or the micro-fissures, formed at early stage of diagenesis, orange-red or light brown in fluorescent light; c/ d-fluid inclusions distributed in belts along micro-fissures cutting quartz grains, formed at the late stage of diagenesis, light blue or light green in fluorescent light

indicating that earlier heavy hydrocarbon exists in the inclusions, and the homogenization temperature peak of the associated brine inclusions is at $85-95{ }^{\circ} \mathrm{C}$ (Table 3). The second stage hydrocarbon inclusions were developed after the quartz overgrowth. They are mainly distributed in belts along post-diagenesis micro-fissures cutting quartz grains and are strong light blue and light bluish green in fluorescent light (lower part of Fig. 7). Laser Raman spectra showed that the main components of these inclusions are methane and higher hydrocarbons, and the homogenization temperature peak of the associated brine inclusions is between 110 and $130{ }^{\circ} \mathrm{C}$ (Table 3). This indicates that two stages of gas accumulation took place in the central Sichuan Basin. It is discovered by further analysis (Table 3 ) that the salinity of low temperature inclusions is lower (2\%-13\%), reflecting that the salinity of formation water was lower in this period, and they are the products of the early and middle stages of diagenesis when the source rocks started to become mature, generate substantial gas and enter the reservoir stage. The salinity of high-temperature inclusions is higher (16\%-22\%) and should be the record of the middle and late stages of diagenesis when the salinity increased with the substantial discharge of formation water, and the organic matter was discharged at mature and highly mature stages. The age of the former probably corresponds to the period before and after the end of the Jurassic and that of the latter corresponds to the uplift period occurring at the end of Cretaceous. It is discovered by studying the gas generation and expulsion history of Xujiahe Formation in central Sichuan Basin that there are a total of two stages of gas expulsion, migration, and accumulation: one stage occurred earlier, corresponding to the substantial gas generation period of gas source rocks, and the other stage occurred later, corresponding to tectonic uplift period. The two stages of gas accumulation are both characterized by large-scale 
Table 3 Occurrence and test data of fluid inclusions from Xu2 Member, Penglai area

\begin{tabular}{|c|c|c|c|c|c|c|c|}
\hline Occurrence in mineral deposit & $\begin{array}{l}\text { Distribution } \\
\text { pattern of } \\
\text { inclusions }\end{array}$ & $\begin{array}{l}\text { Type of fluid } \\
\text { inclusions }\end{array}$ & $\begin{array}{l}\text { Size, } \\
\mu \mathrm{m}\end{array}$ & $\begin{array}{l}\text { Gas } \\
\text { liquid } \\
\text { ratio, \% }\end{array}$ & $\begin{array}{l}\text { Single } \\
\text { phase }\end{array}$ & $\begin{array}{l}\text { Homogenization } \\
\text { temperature, }{ }^{\circ} \mathrm{C}\end{array}$ & $\begin{array}{l}\text { Salinity, } \\
\mathrm{wt} \% \mathrm{NaCl}\end{array}$ \\
\hline \multirow{12}{*}{$\begin{array}{l}\text { At dust lane and } \\
\text { inside of quartz } \\
\text { overgrowth }\end{array}$} & Zonal & \multirow{12}{*}{$\begin{array}{l}\text { Hydrocarbon bearing } \\
\text { brine inclusions }\end{array}$} & $3 \times 5$ & $\leq 5$ & Liquid & 89 & 2.90 \\
\hline & Zonal & & $4 \times 7$ & $\leq 5$ & Liquid & 90 & 3.06 \\
\hline & Zonal & & $6 \times 9$ & $\leq 5$ & Liquid & 92 & 3.06 \\
\hline & Zonal & & $3 \times 3$ & $\leq 5$ & Liquid & 90 & 13.7 \\
\hline & Zonal & & $2 \times 6$ & $\leq 5$ & Liquid & 89 & 13.6 \\
\hline & Zonal & & $3 \times 4$ & $\leq 5$ & Liquid & 92 & 13.6 \\
\hline & Zonal & & $4 \times 4$ & $\leq 5$ & Liquid & 90 & 13.7 \\
\hline & Zonal and lineal & & $10 \times 12$ & $\leq 5$ & Liquid & 95 & 4.96 \\
\hline & Zonal and lineal & & $2 \times 12$ & $\leq 5$ & Liquid & 94 & 5.71 \\
\hline & Zonal & & $26 \times 15$ & $\leq 5$ & Liquid & 92 & 6.74 \\
\hline & Zonal & & $15 \times 16$ & $\leq 5$ & Liquid & 92 & 6.88 \\
\hline & Zonal & & $6 \times 8$ & $\leq 5$ & Liquid & 93 & 6.88 \\
\hline \multirow{14}{*}{$\begin{array}{l}\text { Along micro-fissures cutting } \\
\text { quartz grains and overgrowth, } \\
\text { formed at late stage } \\
\text { of diagenesis }\end{array}$} & Zonal & \multirow{14}{*}{$\begin{array}{l}\text { Hydrocarbon } \\
\text { bearing brine } \\
\text { inclusions }\end{array}$} & $2 \times 6$ & $\leq 5$ & Liquid & 116 & 20.2 \\
\hline & Zonal & & $3 \times 6$ & $\leq 5$ & Liquid & 118 & 20.2 \\
\hline & Zonal & & $1 \times 7$ & $\leq 5$ & Liquid & 125 & 20.2 \\
\hline & Zonal & & $1 \times 4$ & $\leq 5$ & Liquid & 125 & 20.2 \\
\hline & Zonal & & $3 \times 7$ & $\leq 5$ & Liquid & 117 & 20.1 \\
\hline & Zonal and lineal & & $10 \times 15$ & $\leq 5$ & Liquid & 128 & 16.9 \\
\hline & Zonal and lineal & & $2 \times 3$ & $\leq 5$ & Liquid & 126 & 17.0 \\
\hline & Zonal and lineal & & $4 \times 6$ & $\leq 5$ & Liquid & 130 & 17.0 \\
\hline & Zonal and lineal & & $3 \times 4$ & $\leq 5$ & Liquid & 129 & 16.9 \\
\hline & Zonal & & $3 \times 4$ & $\leq 5$ & Liquid & 115 & 22.4 \\
\hline & Zonal & & $4 \times 5$ & $\leq 5$ & Liquid & 119 & 20.0 \\
\hline & Zonal & & $2 \times 3$ & $\leq 5$ & Liquid & 116 & 20.0 \\
\hline & Zonal & & $2 \times 10$ & $\leq 5$ & Liquid & 124 & 20.1 \\
\hline & Zonal & & $5 \times 10$ & $\leq 5$ & Liquid & 129 & 20.1 \\
\hline
\end{tabular}

accumulation, the former resulted from gentle structures in the central Sichuan Basin, whereas the latter resulted from overall tectonic uplift (Zhao et al. 2010) (Fig. 8).

\subsection{Geochemical features}

Experimental results show that with the decline of pressure, the carbon isotope ratios of hydrocarbon gas discharged from coal seams become lighter and lighter, and the $\mathrm{C}_{1} /\left(\mathrm{C}_{1}-\mathrm{C}_{5}\right)$ coefficient becomes lower and lower. The gas generated at the late stage of formation burial is discharged first, having higher maturity, whereas the gas adsorbed in coal seams at early stage of formation burial is discharged last, having lower maturity (Table 4). The geochemical features of gas in the western Ordos Basin show that (Dai et al. 2005) the composition and carbon isotope ratios do not match the maturity of the coal measure source rocks. The lower carbon isotope ratio of methane and the lower $\mathrm{C}_{1} /\left(\mathrm{C}_{1}-\mathrm{C}_{5}\right)$ coefficient constitute a contradiction with the higher maturity of source rocks. For instance, the maturity $\left(R_{\mathrm{O}} \%\right)$ of Permo-
Carboniferous coal seams in the Sulige region exceeds $2.0 \%$; however, the gas in some regions is wetter, with the $\mathrm{C}_{1} /\left(\mathrm{C}_{1}-\mathrm{C}_{5}\right)$ coefficient being up to $86 \%$, and the carbon isotope ratio of methane is lighter, -29.96 to $-36.45 \%$, showing that the gas accumulated in the Upper Paleozoic gas field mainly originates from adsorbed gas desorption and free gas expansion in the source kitchen in the uplift period, whereas the gas adsorbed inside source rocks mainly comes from the early and middle mature stage of source rocks, having lower maturity. Therefore, it is normal for it to be different from the current maturity of the source rocks. Moreover, such carbon isotope lightening gradually becomes apparent from the Sulige gas field in the west to the Yulin gas field in the east of the Ordos Basin, which is significantly related to the fact that the strata uplift gradually increased from $800 \mathrm{~m}$ in the west to $1400 \mathrm{~m}$ in the east at the late stage of the basin tectonics. This is because within a certain range, the larger the uplift, the more gas is desorbed from the coal measure, resulting in a large proportion of gas accumulated in the gas field in the uplift period (Fig. 9). 


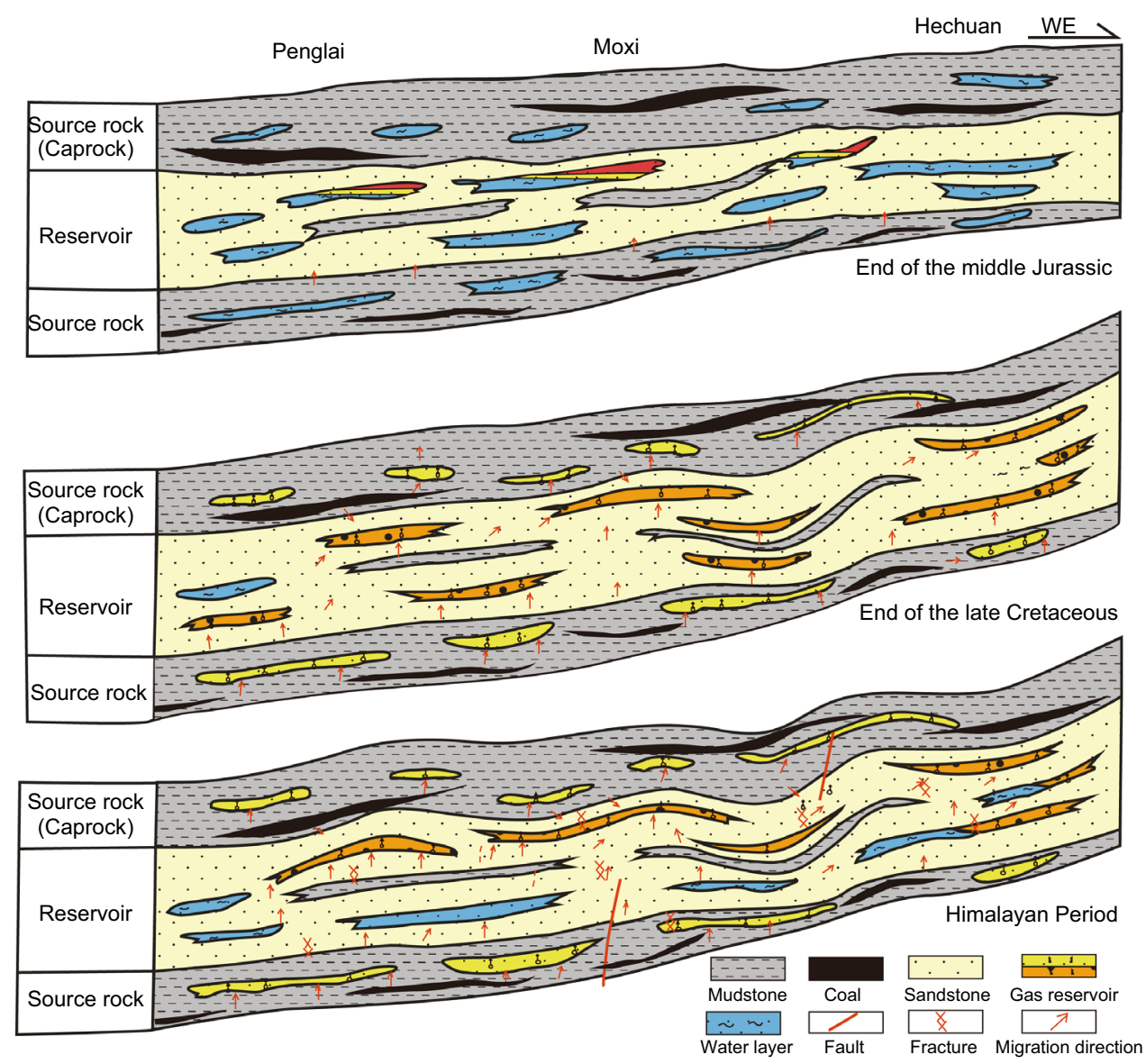

Fig. 8 Gas accumulation model of the Xujiahe Formation in the central Sichuan Basin

Table 4 Composition and carbon isotope of gas discharged by coal under different temperature and pressure conditions

\begin{tabular}{|c|c|c|c|c|c|c|c|c|c|}
\hline Coal sample & Process & $\begin{array}{l}\text { Temperature, } \\
{ }^{\circ} \mathrm{C}\end{array}$ & $\begin{array}{l}\text { Gas yield, } \\
\mathrm{mL} / \mathrm{g}\end{array}$ & $\begin{array}{l}\text { Gas, } \\
\%\end{array}$ & $\begin{array}{l}\mathrm{C}_{1}, \\
\%\end{array}$ & $\begin{array}{l}\mathrm{C}_{2+}, \\
\%\end{array}$ & $\begin{array}{l}\mathrm{C}_{1} /\left(\mathrm{C}_{1}-\mathrm{C}_{5}\right) \\
\text { coefficient }\end{array}$ & $\delta^{13} \mathrm{C}_{1}, \%$ & $\delta^{13} \mathrm{C}_{2}, \%$ \\
\hline \multirow[t]{2}{*}{ Liaohe lignite } & Heating and pressurizing & 450 & 19.4 & 6.9 & 3.7 & 3.2 & 0.6 & -34.4 & -25.7 \\
\hline & Cooling and depressurizing & 350 & & 17.5 & 8.7 & 8.8 & 0.5 & -40.6 & -29.9 \\
\hline \multirow[t]{2}{*}{ Xianfeng lignite } & Heating and pressurizing & 450 & 79.5 & 40.1 & 22.8 & 17.3 & 0.6 & -31.8 & -26.0 \\
\hline & Cooling and depressurizing & 350 & & 9.2 & 6.2 & 3 & 0.7 & -34.5 & -27.4 \\
\hline \multirow[t]{2}{*}{ Taiyuan Formation } & Heating and pressurizing & 450 & 60.8 & 72.7 & 54.6 & 18.2 & 0.8 & -30.1 & -24.5 \\
\hline & Cooling and depressurizing & 350 & & 68.2 & 48.9 & 19.3 & 0.7 & -34.6 & -24.6 \\
\hline \multirow[t]{2}{*}{ Shanxi Formation } & Heating and pressurizing & 450 & 70.25 & 76.3 & 61.6 & 14.7 & 0.8 & -31.5 & -23.0 \\
\hline & Cooling and depressurizing & 350 & & 71 & 59.4 & 11.6 & 0.8 & -33.4 & -23.8 \\
\hline
\end{tabular}

This also suggests that the composition and carbon isotope ratios of the Xujiahe Formation gas in the central Sichuan Basin are inconsistent with the maturity of the source rocks. For instance, the carbon isotope ratio of the $\mathrm{Xu} 2 \mathrm{Member}$ methane in the Hechuan region is lighter ( -39 to $-42 \%$ ), but the maturity $R_{\mathrm{o}}$ of the lower coal measure source rocks is 1.1-1.3, belonging to the substantial gas generation stage of coal measure source rocks. Based on the statistical data from Dai (1992), the carbon isotope ratio of methane should be -32 to $-36 \%$. In addition, the carbon isotopes of ethane and propane are also characterized by lightening, only the lightening amplitude decreases gradually. The experimental results show that such gas with low maturity was possibly formed and stored in the coal measure source rocks at the early stage, but it was discharged, became free gas, and accumulated due to tectonic uplift at the late stage (Fig. 9). 


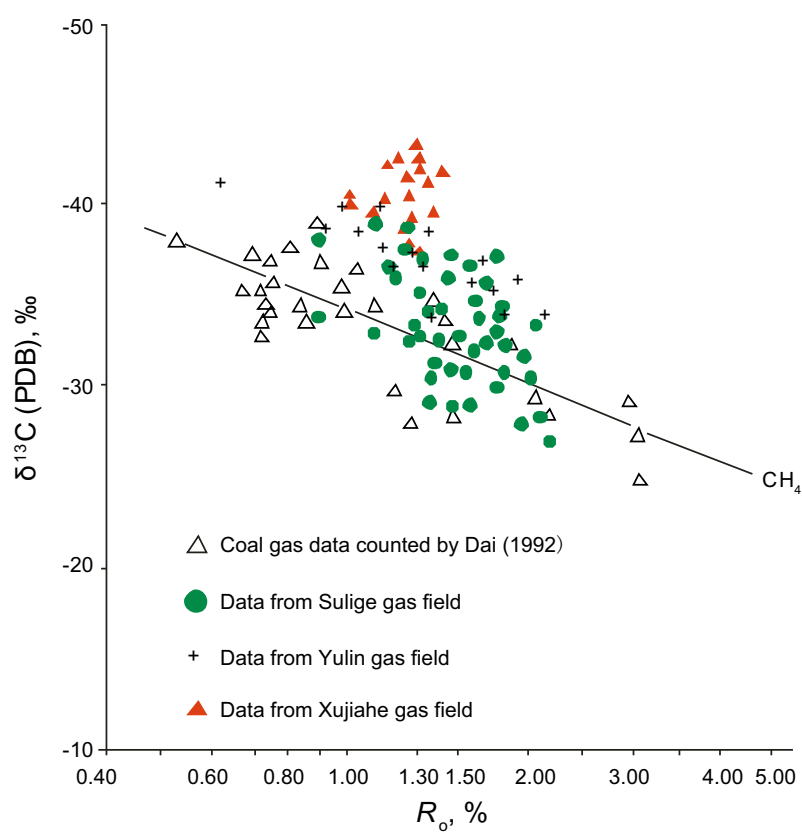

Fig. 9 Carbon isotope ratio versus $R_{\mathrm{O}}$ of Xujiahe Formation gas in the Sichuan Basin and upper Paleozoic gas in the Ordos Basin and typical coal-formed gas

\section{Main gas accumulation pattern and geological significance of uplift period accumulation}

It was generally believed that diffusion was one of the major factors damaging gas reservoirs, and studies show that diffusion is an important mode for gas to migrate with molecular motion (Nelson and Simmons 1992; Lu and Connell 2007; Lu et al. 2008; Korrani et al. 2012). With increasing study of low porosity and permeability reservoir gas, especially on tight gas, diffusion migration is believed as an important way for the gas to migrate and accumulate in tight reservoirs (Liu et al. 2012; Wang et al. 2014). (Liu et al. 2012) point out that the bulk flow under sourcereservoir pressure differentials and the diffusion flow under hydrocarbon concentration differential are two important ways for gas migration and infusion. Experiments and geological analysis show that at the stage of strata uplift, gas generation in source rocks stopped, and the sourcereservoir pressure differential dropped gradually. The combined action of desorption of coal seam adsorbed gas and expansion of free gas in the original pores of the coal seams significantly increased the gas concentration inside the source rocks and provided power for the gas to diffuse and migrate from source rocks to reservoirs.

On the basis of geological analysis of the Xujiahe Formation gas reservoirs in the Sichuan Basin, we calculated bulk flow charge, diffusion flow charge, and diffusion loss in tight sand gas reservoirs. The results show that in the strata uplift period, the average charge rate of diffusion flow reached $0.8 \times 10^{7} \mathrm{~m}^{3} /\left(\mathrm{km}^{2} \cdot \mathrm{Ma}\right)$, and the charge volume approached $56 \times 10^{12} \mathrm{~m}^{3}$, whereas the bulk flow charge of gas mainly occurred in the burial period of the basin, with a charge volume of $127 \times 10^{12} \mathrm{~m}^{3}$, and in the whole gas generation and accumulation history, the gas diffusion loss volume was estimated to be $135 \times 10^{12} \mathrm{~m}^{3}$. As a result, the gas diffusion loss cannot be compensated only by bulk flow charge, and it is hard to form the discovered Xujiahe Formation TCM scale gas field. Therefore, the diffusion charge in the uplift period of formation effectively compensates for the diffusion loss of gas and contributes more to the efficient gas accumulation and preservation of large tight sand gas fields.

The concept of gas accumulation in the uplift period has important theoretical and practical significances. Firstly, it breaks the conventional view that the uplift period is unfavorable for gas accumulation, and secondly it promotes the gas resource extent and potential of the tectonic uplift area. On this basis, many large uplift areas formerly believed to be unfavorable for exploration are reassessed, and the area of favorable gas exploration provinces has been increased.

\section{Discussion}

On the basis of analyzing the coal seam adsorbed and desorbed gas model, this paper uses a great deal of thermal simulation and physical simulation experiments to demonstrate the geological process of gas accumulation in the uplift period of coal-bearing formations. As well, a lot of fluid inclusions and geochemical evidence are available for the analysis of real gas fields, showing that recognition of gas accumulation due to pressure drop and desorption from coal-bearing formations in the uplift period has important theoretical and practical bases and is of great significance to promoting the resource potential of coalbearing strata uplift areas. However, the high-pressure (>20 MPa) coal seam adsorbed and desorbed gas model needs further study, for the adsorption state of methane at high pressure has possibly changed. The ordinary coalbed methane adsorption and desorption simulation experiments are mainly undertaken at pressures of less than $20 \mathrm{MPa}$, and it is important to conduct higher pressure (20-40 MPa) adsorption-desorption gas tests in the future.

\section{Conclusions}

(1) The adsorption-desorption principle of coal seam gas emission and simulation experiment results confirms that pressure drop and desorption occur in the uplift process of coal measure formation, and the 
substantial free gas discharged becomes the gas source in the uplift period. Gas supply strength is estimated as up to (3-6) $\times 10^{8} \mathrm{~m}^{3} / \mathrm{km}^{2}$ in the Upper Paleozoic of the Ordos Basin and the Xujiahe Formation of the Sichuan Basin, which significantly increases the resource potential of tight sand gas. The diffusion charge of desorbed gas in the course of coal measure source rock uplift can compensate for the loss of gas due to diffusion after gas accumulation and contributes more to the formation of large gas fields.

(2) The carbon isotope ratios of gas discharged in the uplift period are lighter than those of gas formed in the burial period. High-temperature and high-salinity inclusions and the physical simulation experiment results obtained under nearly real geological conditions all confirm that large scale gas accumulation can occur in the uplift period of coal measure strata due to pressure drop, desorption, and gas expansion.

(3) This understanding enlarges the exploration potential of tight sand gas. Further geological study needs to be strengthened in regions where the stratigraphic uplift amplitude is large and that were formerly believed to be unfavorable gas accumulation conditions, so as to find more gas resources and reserves.

Open Access This article is distributed under the terms of the Creative Commons Attribution 4.0 International License (http:// creativecommons.org/licenses/by/4.0/), which permits unrestricted use, distribution, and reproduction in any medium, provided you give appropriate credit to the original author(s) and the source, provide a link to the Creative Commons license, and indicate if changes were made.

\section{References}

Anderson RB, Bayer J, Hofer LJE. Equilibrium sorption studies of methane on Pittsburgh Seam and Pocahontas No. 3 Seam Coal. Coal Sci. 1966;386-99.

Ayers WB. Coalbed gas systems, resources, and production and a review of contrasting cases from the San Juan and Powder River Basins. AAPG Bull. 2002;86:1853-90.

Bae JS, Bhatia SK. High-pressure adsorption of methane and carbon dioxide on coal. Energy Fuels. 2006;20(6):2599-607.

Bian CS, Wang HJ, Wang ZC, et al. Controlling factors for massive accumulation of natural gas in the Xujiahe Formation in central Sichuan Basin. Oil Gas Geol. 2009;30(5):548-55 (in Chinese).

British Petroleum Company. BP statistical review of world energy 2012. London: British Petroleum Company; 2012.

Busch A, Krooss BM, Gensterblum Y, et al. High-pressure adsorption of methane, carbon dioxide and their mixtures on coals with a special focus on the preferential sorption behavior. J Geochem Explor. 2003;78-79:671-4.

Clarkson CR, Bustin RM. The effect of pore structure and gas pressure upon the transport properties of coal: a laboratory and modeling study. 1. Isotherms and pore volume distributions. Fuel. 1999;78(11):1333-44.
Crosdale PJ, Beamish BB, Valix M. Coalbed methane sorption related to coal composition. Int J Coal Geol. 1998;35:147-58.

Cui YJ, Li YH, Zhang Q, et al. Characteristic curves of coal adsorbing methane and their application to coalbed methane gathering study. Chin Sci Bull. 2005;50(supplement I):76-81 (in Chinese).

Dai JX. Identification of various genetic natural gases. China Offshore Oil Gas (Geol). 1992;6(1):11-9 (in Chinese).

Dai JX, Li J, Luo X, et al. Alkane carbon isotopic composition and gas source in giant gas fields of Ordos Basin. Acta Petrolei Sin. 2005;26(1):18-26 (in Chinese).

Dai JX, Ni YY, Wu XQ. Tight gas in China and its significance in exploration and exploitation. Pet Explor Dev. 2012;39(3): 257-64 (in Chinese).

Gregory JB, Karen CR. Hysteresis of methane/coal sorption isotherms. In: SPE 15454, 1986.

Hao SS, Cheng ZM, Lv YF, et al. Natural gas reservoir formation and preservation. Beijing: Petroleum Industry Press; 1995 (in Chinese).

Haydel JH, Kobayashi R. Adsorption equilibria in the methanepropane-silica gel system at high pressures. Ind Eng Chem Fundam. 1967;6(4):546-54.

He DB, Jia AL, Ji G, et al. Well type and pattern optimization technology for large scale tight sand gas, Sulige gas field. Pet Explor Dev. 2013;40(1):257-64 (in Chinese).

Holditch SA. Tight gas sands. J Pet Technol. 2006;58:86-94.

Johnson RC, Rice DD. Occurrence and geochemistry of natural gases, Piceance Basin, Northwest Colorado. AAPG Bull. 1990;74(6): 805-29.

Korrani AKN, Gerami S, Ghotbi C, et al. Investigation on the importance of the diffusion process during lean gas injection into a simple synthetic depleted naturally fractured gas condensate reservoir. Pet Sci Technol. 2012;30(7):655-71.

Kuuskraa VA, Bank GC. Gas from tight sands, shales: a growing share of US supply. Oil Gas J. 2003;101(47):34-43.

Law BE. Basin-centered gas systems. AAPG Bull. 2002;86(11): 1891-919.

Li JZ, Guo BC, Zheng M, et al. Main types, geological features and resource potential of tight sandstone gas in China. Nat Gas Geosci. 2012;23(4):607-15 (in Chinese).

Liu GD, Zhao ZY, Sun ML, et al. New insights into natural gas diffusion coefficient in rocks. Pet Explor Dev. 2012;39(5): 559-66 (in Chinese).

Lu HZ. Fluid inclusions. Beijing: Science Press; 2005 (in Chinese).

$\mathrm{Lu} \mathrm{M}$, Connell LD. A model for the flow of gas mixtures in adsorption dominated dual porosity reservoirs incorporating multi-component matrix diffusion: Part I. Theoretical development. J Pet Sci Eng. 2007;59(1-2):17-26.

Lu M, Connell LC, Pan ZJ. A model for the flow of gas mixtures in adsorption dominated dual-porosity reservoirs incorporating multicomponent matrix diffusion-Part II Numerical algorithm and application examples. J Petrol Sci Eng. 2008;62(3-4):93-101.

Masters JA. Deep basin gas trap, western Canada. AAPG Bull. 1979;63(2):152.

Mavor MJ, Owen LB, Pratt TJ. Measurement and evaluation of coal sorption isotherm data. In: SPE annual technical conference and exhibition, SPE-20728-MS, New Orleans, Louisiana, 23-26 September 1990.

Mukhopadhyay PK, Macdonald DJ. Relationship between methane/generation and adsorption potential, micropore system, and permeability with composition and maturity-examples from the Carboniferous coals of Nova Scotia, Eastern Canada. In: Proceeding of the 1997 coalbed methane symposium, Tuscaloosa, 1997, p. 183-93.

Murata K, El-Merraoui M, Kaneko K. A new determination method of absolute adsorption isotherm of supercritical gases under high pressure with a special relevance to density-functional theory study. J Chem Phy. 2001;114:4196-205. 
Nelson JS, Simmons EC. The quantification of diffusive hydrocarbon losses through cap rocks of natural gas reservoirs-a reevaluation, discussion. AAPG Bull. 1992;76(11):1839-41.

Radovic LR, Menon VC, Leon LY, et al. On the porous structure of coals: evidence for an interconnected but constricted micropore system and implications for coalbed methane recovery. Adsorption. 1997;3(3):221-32.

Rossi C, Goldstein RH, Ceriani A, et al. Fluid inclusions record thermal and fluid evolution in reservoir sandstones, Khatatba Formation, Western Desert, Egypt: a case for fluid injection. AAPG Bull. 2002;86(10):1773-99.

Ruppel TC, Grein CT, Bienstock D. Adsorption of methane on dry coal at elevated pressure. Fuel. 1974;53:152.

Sang SX, Zhu YM, Zhang J. Solid-gas interaction mechanism of coalabsorbed gas (II) - Physical process and theoretical model of coal-adsorbed gas. Nat Gas Ind. 2005;25(1):16-8 (in Chinese).

Smith TM, Sayers CM, Sondergeld CH. Rock properties in lowporosity/low-permeability sandstones. Lead Edge. 2009;28(1): $48-59$.

Su XB, Chen R, Lin XY, et al. Application of adsorption potential theory in the fractionation of coalbed gas during the process of adsorption/desorption. Acta Geol Sin. 2008;82(10):830-7 (in Chinese).

Tian FH, Jiang ZX, Zhang XB, et al. Preliminary study on contribution of rift-erosion to oil and gas accumulation. Acta Geol Sin. 2007;81(2):273-9 (in Chinese).

Tissot BP, Welte DH. Petroleum formation and occurrence. New York: Springer; 1984.

Wang HJ, Tian YC. Applications of general characteristics of fluid inclusions to the study of oil and gas pool formation. Pet Explor Dev. 2000;27(3):50-2 (in Chinese).

Wang HJ, Bian CS, Liu GD, et al. Two highly efficient accumulation models of large gas fields in China. Pet Sci. 2014; 11(1):21-31.

Wang SW, Chen ZH, Zhang M. Pore and microfracture of coal matrix block and their effects on the recovery of methane from coal. Earth Sci. 1995;20(5):557-61 (in Chinese).

Yang RT, Saunders JT. Adsorption of gases on coals and heat-treated coals at elevated temperature and pressure. Fuel. 1985;64: 616-25.

Zeng JH, Jin ZJ. The physical simulation of petroleum second migration and accumulation. Beijing: Petroleum Industry Press; 2002. p. $25-7$.
Zeng LB. Microfracturing in the Upper Triassic Sichuan Basin tightgas sandstones: tectonic, overpressure, and diagenetic origins. AAPG Bull. 2010;94(12):1811-25.

Zhang CL, Li TR, Xiong QH. Relationship between lithostructure and fracture distribution in coal. Coal Geol Explor. 2000;28(5): 26-30 (in Chinese).

Zhang E, Hill RJ, Katz BJ, et al. Modeling of gas generation from the Cameo coal zone in the Piceance Basin, Colorado. AAPG Bull. 2008;92(8):1077-106.

Zhang HF, Fang CL, Gao XZ, et al. Petroleum geology. Beijing: Petroleum Industry Press; 1999 (in Chinese).

Zhang LP, Bai GP, Luo XR, et al. Diagenetic history of tight sandstones and gas entrapment in the Yulin Gas Field in the central area of the Ordos Basin, China. Mar Pet Geol. 2009a;26(6):974-89.

Zhang SC, Mi JK, Liu LH, et al. Geological features and formation of coal-formed tight sandstone gas pools in China: cases from Upper Paleozoic gas pools, Ordos Basin and Xujiahe Formation gas pools, Sichuan Basin. Pet Explor Dev. 2009b;36(3):320-30 (in Chinese).

Zhao WZ, Bian CS, Xu CC, et al. Assessment on gas accumulation potential and favorable plays within the $\mathrm{Xu}-1,3$ and 5 Members of Xujiahe Formation in Sichuan Basin. Pet Explor Dev. 2011;38(4):1-12 (in Chinese).

Zhao WZ, Hu SY, Wang HJ, et al. Large-scale accumulation and distribution of medium-low abundance hydrocarbon resources in China. Pet Explor Dev. 2013;40(1):1-14 (in Chinese).

Zhao WZ, Wang HJ, Shan JZ, et al. Geological analysis and physical modeling of structural pumping in high effective formation of Kela 2 gas field. Sci China Ser D Earth Sci. 2006;49(10):1070-8.

Zhao WZ, Wang HJ, Xu CC, et al. Reservoir-forming mechanism and enrichment conditions of the extensive Xujiahe Formation gas reservoirs, central Sichuan Basin. Pet Explor Dev. 2010;37(2): 146-57 (in Chinese).

Zhao WZ, Wang ZC, Zhu YX, et al. Forming mechanism of lowefficiency gas reservoir in Sulige Gas Field of Ordos Basin. Acta Pet Sin. 2005;26(5):5-9 (in Chinese).

Zhao ZG, Tang XY, Zhang GM. Experiment and significance of isothermal adsorption of coal on methane under higher temperature. Coal Geol Explor. 2001;29(4):29-31 (in Chinese).

Zou CN, Zhu RK, Liu KY, et al. Tight gas sandstone reservoirs in China: characteristics and recognition criteria. J Pet Sci Eng. 2012;88-89:82-91. 